\title{
Studying the impact of the organizational commitment on the job performance
}

\author{
Mojtaba Rafiei ${ }^{\mathrm{a}}$, Mohammad Taghi Amini ${ }^{\mathrm{b}}$ and Navid Foroozandeh ${ }^{\mathrm{*}}$
}

${ }^{a}$ Assistant professor, Department of Public Administration, Payame Noor University, PO Box 19395-3697 Tehran, Iran

${ }^{b}$ Associate professor, Department of Management, Payame Noor University, PO Box 19395-3697 Tehran, Iran

${ }^{c}$ M.A Student of EMBA, Department of Management, Payame Noor University, PO Box 19395-3697 Tehran, Iran

\section{H R O N I C L E A B S T R A C T}

Article history:

Received January 28, 2014

Accepted 20 June 2014

Available online

June 262014

Keywords:

Organizational Commitment

Job Performance

Affective Commitment

Normative Commitment

Continuance Commitment

\begin{abstract}
Success of any organization depends on the performance of its employees. Enhancing organizational commitment among employees is an important aspect to perform better. The purpose of this study is to examine the effect of three components of organizational commitment; namely Affective, Continuance and Normative commitment, on employee's performance. The study is applied among 244 employees of Cooperatives, Labor and Social Welfare department of Markazi Province using a single-stage cluster sampling. The study uses a standard questionnaire for organizational commitment developed by Allen and Meyer and job performance questionnaire developed by Patterson were used to gather data. Structural equations modeling (SEM) technique has been used for data analysis. The result of this analysis indicates that the organizational commitment had a positive significant effect on the job performance. In addition, the study also showed that all three dimensions of organizational commitment, Affective, continuance, and normative commitment, had a positive significant effect on the job performance. From the findings, it has been proved that job performance was strongly associated with employee's commitment.
\end{abstract}

\section{Introduction}

Over the past few decades, substantial amount of efforts have been devoted on understanding the nature, antecedents, and consequences of organizational commitment. Employee commitment is important because high levels of commitment may easily lead to various favorable organizational outcomes. Meta-analyses indicate that commitment is negatively associated with turnover (CooperHakim \& Viswesvaran, 2005), absenteeism (Farrel \& Stamm, 1988), and counterproductive behavior (Dalal, 2005) and positively associated with job satisfaction (Cooper-Hakim \& Viswesvaran, 2005), motivation (Mathieu \& Zajac, 1990), and organizational citizenship behavior (Riketta, 2002). Low commitment is also associated with low levels of morale (DeCotiis \& Summers, 1987) and decreased measures of altruism and compliance (Schappe, 1998). Finally, non-committed employees may *Corresponding author.

E-mail addresses: n_foroozandeh2012@yahoo.com (N. Foroozandeh) 
explain the organization in negative terms to outsiders thereby inhibiting the organization's ability to recruit high-quality employees (Mowday et al., 1982). In the recent years, the effects of organizational psychological and employees' behavioral issues such as organizational commitment and the influence of organizational commitment on the employee job performance have been considered. Many organizations try to provide appropriate solutions to create the desirable optimal environments to increase job satisfaction, commitment to the profession and employee's job performance. The study of employee's job performance and organizational commitment plays essential role for top-level management of the organizations. Somers and Birnbaum (1998) studied the relationship of career commitment to performance effectiveness and reported a positive relationship between these two factors. Jackofsky (1984) reported that low commitment was leading to high rate of turnover, whereas higher the level of job satisfaction through job security may entail high level of organizational commitment which further leads to improved employees job performance. Job performance has been defined as work performance in terms of quantity and quality expected from each employee (business dictionary).

Meyer and Allen (1990) suggested three kinds of organizational commitment that are, affective commitment, which measures an employee's emotional attachment to, identification with, and involvement in the organization, normative commitment reflects pressures on an employee to remain with a firm resulting from firm obligations. Continuance commitment refers commitment associated with the expenses that employees perceive are associated with leaving the organization. Commitment of employees can be an important instrument for improving the performance of the organizations. Jaramillo et al. (2005) conducted a meta-analysis comprising of 51 empirical studies and reported positive relationship between organizational commitment and job performance. Another study showed that more committed employees had higher tendency to perform well and lower tendency to leave their jobs (Mathieu \& Zajac, 1990). A study conducted by Chughtai and Zafar (2006), among university teacher of Pakistan concluded that highly committed teachers outperform vis-à-vis uncommitted teachers. This study primarily focuses on the impacts of low/high commitment towards the employee's job performance.

\section{Literature review}

\subsection{Organizational commitment}

The key to an organizational success depends entirely on the commitment of employees toward organization. Commitment toward organization is more than just a formal membership; it encompasses the attitude to firm and willingness to pursue all things for the sake of firm. Organizational commitment is a situation where an employee in line with a specific organization as well as the goals and wishes to maintain membership in organization (Robbins \& Judge, 2007). Bakan et al. (2011) stated, the success of an organization depends not only on how the organization makes the most human competences, but also how it encourages commitment to an organization

\subsubsection{Affective commitment}

Affective commitment is described as the affective desire on the part of individuals employed in a firm to continue to work in the organization because of detecting themselves with the organization (Yavuz, 2010). Employee's emotional bond to the organization has been considered an essential determinant of dedication and loyalty. Qaisar et al. (2012) stated, Affective commitment is based on worker's emotional association, participation and recognition in the organization.

\subsubsection{Continuance commitment}

The second dimensions of organizational dimensions of Allen and Meyer (1990) is continuance commitment, which is based on the theory of investments. When employees enter into a particular firm, 
they are bound to have a link with the organization or committed to remain with the organization because of insufficient alternative opportunity or awareness of the expenses associated with leaving the organization (Dixit \& Bhatti, 2012).

\subsubsection{Normative Commitment}

Normative Commitment reflects commitment based on perceived obligation towards the organization, for instance rooted in the norms of reciprocity (Jaros, 2007). Normative commitment reflects a feeling of duty to continue working with the organization. There are people who have a high level of normative commitment feels that they remain in the current organization.

\subsection{Job performance}

Performance is described as the attained outcome of actions with the skills of employees who perform in some situation (Prasetya \& Kato, 2011). Kahya (2009) stated that job performance had been studied as an important variable in industrial and organizational psychology literature. Campbell et al. (1990) defined the job performance as behaviors executed in line with the set objectives of the organization. Swasto (1996) stated that employee performance was the actions or the completion of errands accomplished by individuals within specific period of time. Performance refers to the amount of effort, initiative, and maintenance of standards and commitment displayed by individuals while performing the job tasks (Mguqulwa, 2008).

\subsection{Oraganizational commitment-Job performance}

Dixit and Bhati (2012) found that the Employees Commitment (Affective, Normative, continuous) were significantly associated with sustained productivity in Auto component industry. They reported that there were positive relationships between the three commitments (affective, continuance and normative commitment) and sustained productivity of the organization. Qaisar et al. (2012) discussed about the effects of organizational commitment on employee's performance. They examined the effect of three components of organizational commitment (affective, continuance and normative commitment) on performance of police officers in Pakistan. Sinclair et al. (2005) drew from prior research on organizational commitment to propose a framework of affective and continuance commitment profiles. They reported that the free agents received substantially poorer supervisor ratings of performance, organizational citizenship behavior, and antisocial behavior than any other group. Suliman and Lles (2002) explored the nature of organizational commitment in three industrial units in Jordan by applying employees' job performance and five demographic variables. Their research disclosed that that organizational commitment comprises three-dimensional concept. The findings also uncovered a positive relationship between commitment (all the three components) and job performance.

\subsection{Research Model}

The conceptual model of research is illustrated in Fig. 1 as follows,

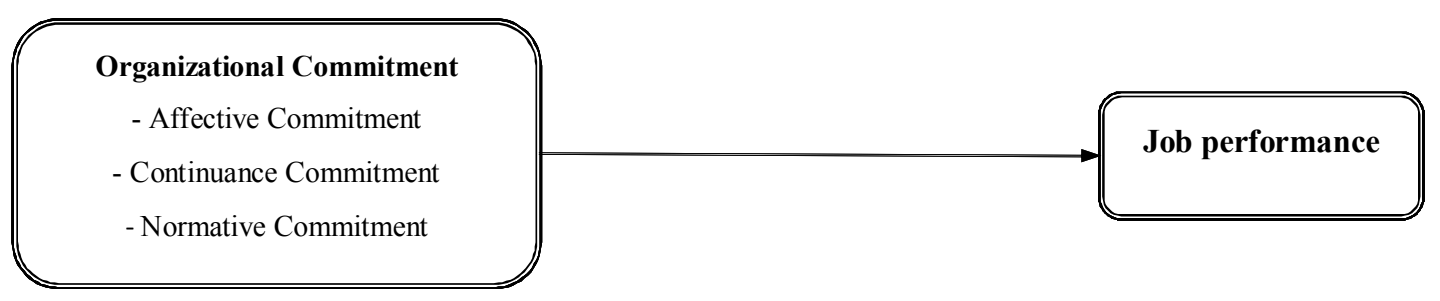

Fig. 1. Conceptual Model of research

The study has been accomplished in one of Iranian organizations located in Markazi province. 


\subsection{Research hypotheses}

\section{Main Hypotheses}

$\mathrm{H}_{1}$ : Organizational commitment has a significant positive effect on employee's performance.

$\mathrm{H}_{2}$ : Affective commitment has a significant positive effect on employee's job performance.

$\mathrm{H}_{3}$ : Continuance commitment has a significant positive effect on employee's job performance.

$\mathrm{H}_{4}$ : Normative commitment has a significant positive effect on employee's job performance.

\section{The research methodology}

The present study is applied in terms of goal. The research method is survey and statistical method is descriptive. Using survey method or field research is an ordered information collecting method that can be used for detecting relationship between various variables.

\subsection{Statistical population, sample size and sampling method}

Statistical population of this study is all officers and employees of cooperatives, labor and social welfare department of Markazi province. Sample size can be determined between 5 and 15 per measured variable, in the structural equation modeling methodology.

$$
5 q \leq n \leq 15 q
$$

where $q$ is the number of observed variables (items of questionnaire) and $n$ represents the sample size. Considering the 7 observed variables for each measurement, the sample included 273 clients which ultimately 244 collected questionnaires were measured and analyzed. In this research, single-stage cluster sampling method was used.

\subsection{Data collection and Data analysis method}

For data collection in this study, two standard questionnaires have been used. All three components of organizational commitment (affective commitment, continuance commitment, and normative commitment) were measured using scale developed by Meyer and Allen (1991). Measuring scale for each component consisted of eight items. To measure the perceived employee performance fifteen items scale developed by Patterson (1990) was used. Five point Likert Scale was used to measure the responses. For data analysis and testing of the research hypothesis, have been used of the inferential statistical and the structural equation modeling method by using of the LISREL 8.80 software.

\subsection{Validity and Reliability of questionnaire}

Some specialists usually determine the content validity of a test. This study has used the standardized questionnaires of Allen and Meyer organizational commitment (1991) and Patterson's job performance (1990).

Table 1

The reliability of measuring instruments

\begin{tabular}{ccc}
\hline Variable & Cronbach's $\alpha$ & Guttman coefficient \\
\hline Organizational commitment & 0.89 & 0.83 \\
Job performance & 0.91 & 0.89 \\
Affective commitment & 0.72 & 0.70 \\
Continuance commitment & 0.75 & 0.71 \\
Normative commitment & 0.79 & 0.72 \\
\hline Total & 0.92 & 0.86 \\
\hline
\end{tabular}


These questionnaires have been used in several studies and therefore, the used measurement instruments in this study was properly validated, and in fact, its validity has been obtained via the content of it. As well as, the validity of this questionnaire has confirmed by faculty advisors and several people that they are valid. In this study, the reliability coefficients were calculated by using of both Cronbach's alpha and Guttman spilt-half coefficient (Table 1).

\section{Research Findings}

\subsection{Test of normality}

The normality of data distribution has been verified using Kolmogorov-Smirnov test and the results are summarized in Table 2 as follows,

Table 2

The results of Kolmogorov - Smirnov test

\begin{tabular}{ccc}
\hline & Kolmogorov-Smirnov Z & Significant level. \\
\hline Organizational commitment & 0.916 & 0.37 \\
Job performance & 1.344 & 0.052 \\
Affective commitment & 1.359 & 0.050 \\
Continuance commitment & 1.236 & 0.094 \\
Normative commitment & 1.338 & 0.056 \\
\hline
\end{tabular}

As shown in Table 2, the significance level for all variables, were higher than the two tailed of 0.05, and therefore the assumption of normality is at $95 \%$ approval.

\subsection{Structural Equation models}

As noted, the hypotheses of one to four are examined based on confirmatory factor analysis and structural equations modeling techniques. Before a separate and detailed review of each of the models, Table 3 shows the symbols in the structural models.

Table 3

The used abbreviations symbols guide in the models

\begin{tabular}{cccc}
\hline Abbreviation & Variable title & Abbreviation & Variable title \\
\hline OC & Organizational Commitment & $\mathrm{C} 1, \mathrm{C} 2, \ldots, \mathrm{C} 8$ & Affective Commitment items \\
$\mathrm{AC}$ & Affective Commitment & $\mathrm{C} 9, \mathrm{C} 10, \ldots, \mathrm{C} 16$ & Continuance Commitment items \\
$\mathrm{CC}$ & Continuance Commitment & $\mathrm{C} 17, \mathrm{C} 18, \ldots, \mathrm{C} 24$ & Normative Commitment items \\
$\mathrm{NC}$ & Normative Commitment & $\mathrm{P} 1, \mathrm{P} 2, \ldots, \mathrm{P} 15$ & Job performance items \\
$\mathrm{PER}$ & Job performance & --- & ---- \\
\hline
\end{tabular}

\subsubsection{Model 1}

The evaluations of the effects of organizational commitment on employee's performance are summarized in Table 4 and Fig. 2.

Table 4

Fit indexes of model 1

\begin{tabular}{cccccccccc}
\hline Index & P_value & $\chi^{2} /$ df & RMSEA & CFI & NFI & NNFI & GFI & IFI & RMR \\
\hline Acceptable Value & $<0.05$ & $<5$ & $<0.1$ & $>0.9$ & $>0.9$ & $>0.9$ & $>0.9$ & $>0.9$ & $<0.05$ \\
Value & 0.00 & 1.47 & 0.044 & 0.99 & 0.97 & 0.99 & 0.92 & 0.99 & 0.030 \\
\hline
\end{tabular}

\subsubsection{Model 2}

The evaluations of effects of affective commitment on employee's performance are summarized in Table 5 and Fig. 3. 


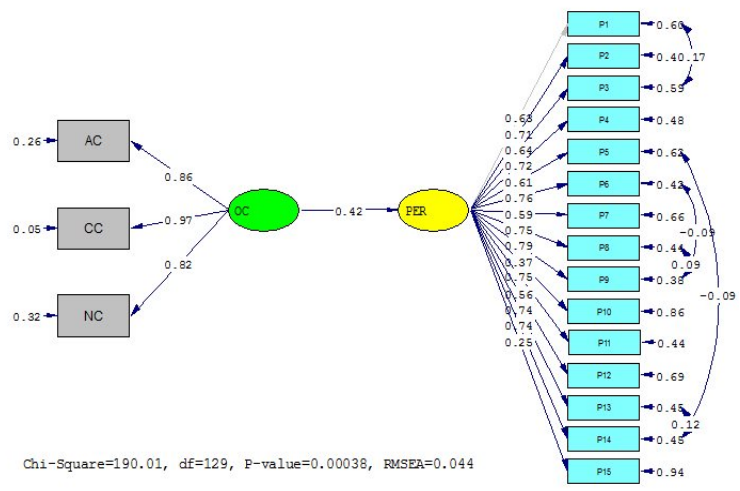

Fig. 2. The model 1 in the standard estimation state

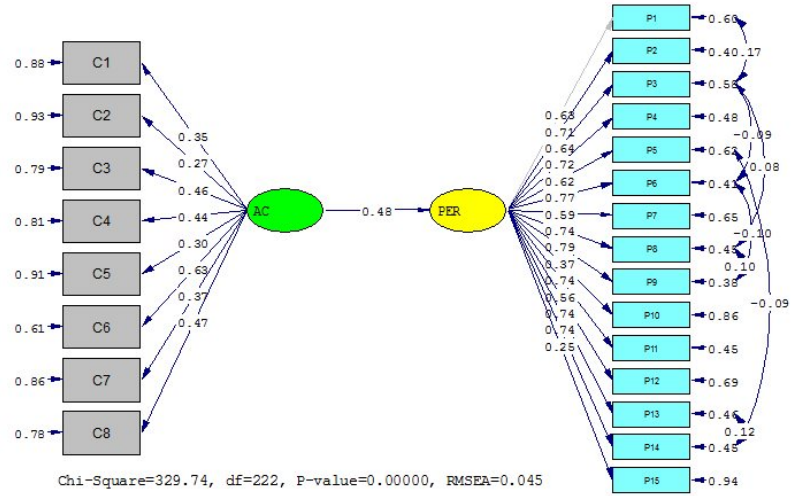

Fig. 3. The model 2 in the standard estimation state

Table 5

Fit indexes of model 2

\begin{tabular}{cccccccccc}
\hline Index & P_value & $\chi^{2} /$ df & RMSEA & CFI & NFI & NNFI & GFI & IFI & RMR \\
\hline Acceptable Value & $<0.05$ & $<5$ & $<0.1$ & $>0.9$ & $>0.9$ & $>0.9$ & $>0.9$ & $>0.9$ & $<0.05$ \\
Value & 0.00 & 1.49 & 0.045 & 0.98 & 0.94 & 0.97 & 0.90 & 0.98 & 0.048 \\
\hline
\end{tabular}

\subsubsection{Model 3}

The evaluations of effects of continuance commitment on employee's performance are summarized in Table 6 and Fig. 4.

Table 6

Fit indexes of model 3

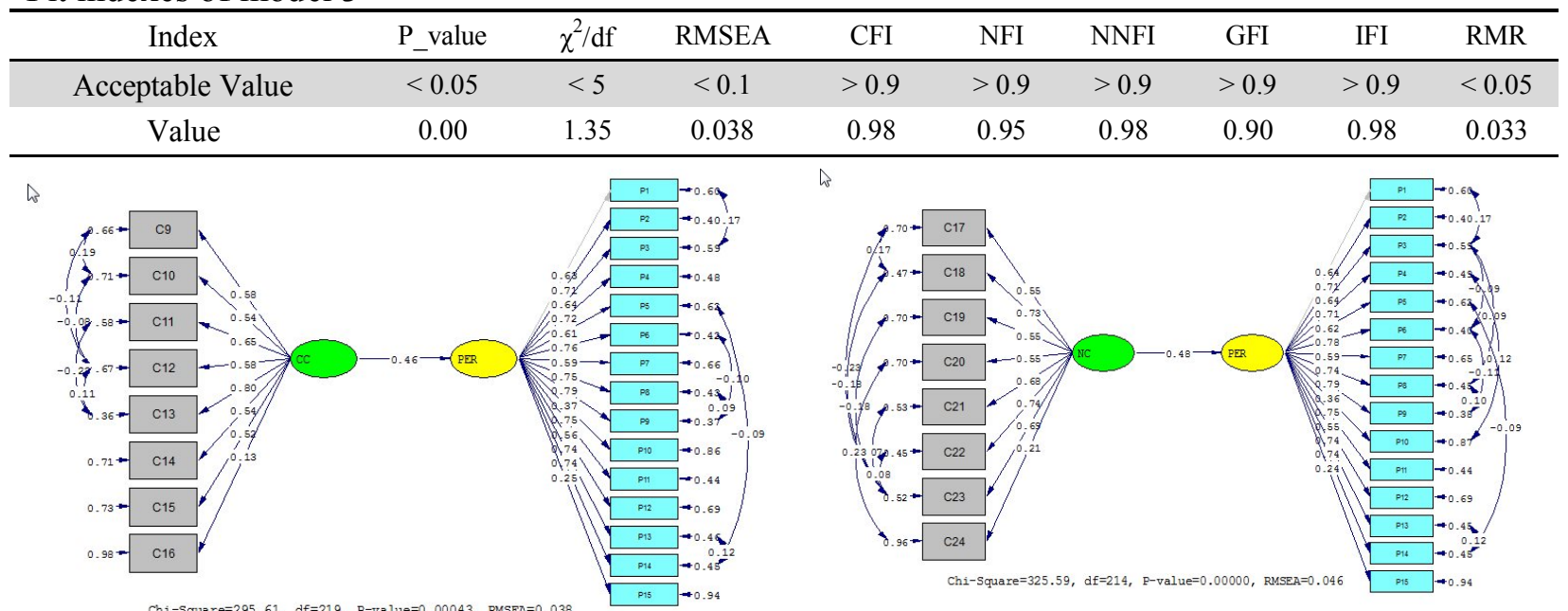

Fig. 4. The model 3 in the standard estimation state

Fig. 5. The model 4 in the standard estimation state

\subsubsection{Model 4}

The evaluations of effects of normative commitment on employee's performance are summarized in Table 7 and Fig 5.

Table 7

Fit indexes of model 4

\begin{tabular}{cccccccccc}
\hline Index & P_value & $\chi^{2} / \mathrm{df}$ & RMSEA & CFI & NFI & NNFI & GFI & IFI & RMR \\
\hline Acceptable Value & $<0.05$ & $<5$ & $<0.1$ & $>0.9$ & $>0.9$ & $>0.9$ & $>0.9$ & $>0.9$ & $<0.05$ \\
Value & 0.00 & 1.52 & 0.046 & 0.98 & 0.95 & 0.98 & 0.90 & 0.98 & 0.039 \\
\hline
\end{tabular}




\subsection{Test of research hypotheses}

Based on the results, we can confirm all hypotheses of the survey and Table 8 shows details of our findings.

Table 8

The effects of commitment dimensions on employee's performance

\begin{tabular}{ccccc}
\hline Model & Relationships & $\begin{array}{c}\text { Path coefficient } \\
\text { Direct effect }\end{array}$ & T-statistic & Results \\
\hline 1 & OC on PER & 0.42 & 5.70 & $\mathrm{H}_{1}$ accepted \\
2 & AC on PER & 0.48 & 5.59 & $\mathrm{H}_{2}$ accepted \\
3 & CC on PER & 0.46 & 5.89 & $\mathrm{H}_{3}$ accepted \\
4 & NC on PER & 0.48 & 6.15 & $\mathrm{H}_{4}$ accepted \\
\hline
\end{tabular}

\section{Conclusions and recommendations}

In the light of statistical results, it transpired that the role of organizational commitment had significant impacts for a staff's performance in this organization. The findings indicate the simultaneous effect of affective, continuance and normative commitments on job performance of employee was significantly positive and those employees who had strong commitment in all three dimensions could perform better. These results are in line with some of previous studies (e.g. Suliman \& Lles 2000; Khan et al., 2010; Mehmud et al., 2010; Qaisar, et al., 2012) who found positive impact of three components of organizational commitment on performance of personnel in various work settings. However, results also contradicted with findings of few researchers who reported that continuance commitment among employees correlate negatively with their performance (e.g. Meyer et al.'s 1989; Cropanzano et al., 1993). This implies that the organization may acquire better performance results by absorbing employees for affective commitment, increasing sunk costs for employees if they leave organization for continuance commitment and increasing their obligation level for building normative commitment. The research study invites attention of top management and policy makers of this organization to take measures to enhance employees' performance through increased commitment level. Improved employee performance results is aim for every organization, therefore this study has highlighted three components of organizational commitment as important factor, which can contribute towards performance improvement of employees.

\section{References}

Allen, N. J., \& Meyer, J.P. (1990). The measurements and antecedent of affective, continuance and normative commitment to the organization. Journal of Occupational Psychology, 63, 1-18.

Bakan, I., Büyükbee, T., \& Erahan, B. (2011). An investigation of organizational commitment and education level among employees. International Journal of Emerging Sciences, 1(3), 231-245.

Campbell, J. P., McCloy, R. A., Oppler, S. H., \& Sager, C. E. (1993). A theory of performance. In: Schmitt N, \& Borman WC, (Eds). Personnel selection in organizations. (pp. 37-70). San Francisco (CA): Jossey-Bass.

Chughtai, A.A., \& Zafar, S. (2006). Antecedents and consequences of organizational commitment among Pakistani University Teachers, Applied H.R.M Research, 11(1), 39-64.

Cooper-Hakim, A., \& Viswesvaran, C. (2005). The construct of work commitment: Testing an integrative framework. Psychological Bulletin, 131(2), 241-259.

Cropanzano, R., James, K., \& Konovsky, M. A. (1993). Dispositional affectivity as a predictor of work attitudesand job performance. Journal of Organizational Behavior, 14, 595-606.

Dalal, R. S. (2005). A meta-analysis of the relationship between organizational citizenship behavior and counterproductive work behavior. Journal of Applied Psychology, 90(6), 1241-1255

DeCotiis, T.A., \& Summers, T.P. (1987). A path analysis of a model of the antecedents and consequences of organizational commitment. Human Relations, 40, 445-470. 
Dixit, V., \& Bhati, M. (2012). A Study about Employee Commitment and Its Impact on Sustained Productivity in Indian Auto-Component Industry. European Journal of Business and Social Sciences, 1(6). 34-51.

Farrel, D., \& Stamm, C. L. (1988). Meta-analysis of the correlates of employee absence. Human relations, 41, 211-227.

Jackofsky, E. F. (1984). Turnover and job performance: An integrated process model. Academy of Management Review, 9(1), 74-83.

Jaramillo, F, Mulki, J. P. \& Marshall, G. W. (2005). A meta-analysis of the relationship between organizational commitment and salesperson job performance: 25 years of research. Journal of Business Research, 58, 705-714.

Jaros, M. (2007). Meyer and Allen Model of Organizational Commitment: Measurement Issues. Southern University College of Business, USA.

Kahya, E. (2009). The effects of job performance on effectiveness. International Journal of Industrial Ergonomics, 39, 96-104.

Khan, M. R., Ziauddin, Jam, F. A., \& Ramay, M. I. (2010). The impacts of organizational commitment on employee job performance. European Journal of Social Sciences, 15(3), 292-298.

Mathieu, J. E., \& Zajac, D. M. (1990). A review and meta-analysis of the antecedents, correlates, and consequences of organizational commitment. Psychological Bulletin, 108, 171-94.

Mehmud, S. T., Ali, N., Baloch, Q. B., \& Khan, Z. (2010). Relationship between organizational commitment and perceived employees performance. Interdisciplinary Journal of Contemporary Research in Business, 2(8), 225-233.

Meyer, J. P., Paunonen, S. V., Gellatly, I. R., Goffin, R. D., \& Jakson, D. N. (1989). Organizational commitment and job performance: it's the nature of commitment that counts. Journal of Applied Psychology, 74 (1), 152-56.

Meyer, J. P., Stanley, D. J., Herscovitch, L., \& Topolnytsky, L. (2002). Affective, Continuance, and Normative Commitment to the Organization: A Meta-analysis of Antecedents, Correlates, and Consequences. Journal of Vocational Behavior, (61), 20-52.

Mguqulwa, M. (2008). The Relationship between organizational commitment and work performance in an Agricultural Company. University of South Africa.

Mowday, R. T., Porter, L. W., \& Steers, R. M. (1982). Employee-organization linkages: The psychology of commitment, absenteeism, and turnover (Vol. 153). New York: Academic Press.

Prasetya, A. \& Kato, M. (2011). The Effect of Financial and Non-Financial Compensation to the Employee Performance. The 2nd International Research Symposium in Service management, Yogyakarta, Indonesia.

Qaisar, M.U., Rehman, M.S., \& Suffyan, M. (2012). Exploring Effects of Organizational Commitment on Employee Performance: Implications for Human Resource Strategy. Interdisciplinary Journal of Contemporary Research in Business, 3(11), 248-255.

Riketta, M. (2002). Attitudinal organizational commitment and job performance: a metaanalysis. Journal of Organizational Behavior, 23(3), 257-266.

Robbins, S.P., \& Judge, T.A. (2007). Organizational Behavior (12th. Ed.). Prentice Hall.

Schappe, S. P. (1998). The influence of job satisfaction, organizational commitment, and fairness perceptions on organizational citizenship behavior.The Journal of Psychology, 132(3), 277-290.

Sinclair, R.R., Tucker, J.S., \& Cullen, J.C. (2005). Performance Differences among four organizational commitment profiles. Journal of Applied Psychology, 90(6), 1280-1287.

Somers, M. J., \& Birnbaum, D. (1998). Work-related commitment and job performance: it's also the nature of the performance that counts. Journal of Organizational Behavior, 19(6), 621-634.

Suliman, A. \& Iles, P. (2000). Is continuance commitment beneficial to organizations? Commitmentperformance relationship: a new look. Journal of Managerial Psychology, 15 (5), 407-426.

Swasto, B. (1996). Human resource development and its effect on performance and rewards, Malang: FIA Unibraw-Malang.

Yavuz, M. (2010). The effect of teachers' perception of organizational justice and culture on organizational commitment. African Journal of Business Management, 4(5), 695-701. 